\title{
Hubungan Pemberian Asi Ekslusif, Berat Bayi Lahir Dan Pola Asuh Dengan Kejadian Stunting Di Wilayah Kerja Puskesmas Reubee Kabupaten Pidie
}

\author{
Relationship Of Exclusive Assesment, Birth Weight And Original \\ Patterns With Stunting Events In Reubee Puskesmas Public Working \\ Areas \\ Agustina*1, Irma Hamisah $^{2}$ \\ *Koresponding penulis: ${ }^{1,2}$ Fakultas Kesehatan Masyarakat Universitas Muhammadiyah Aceh. Banda Aceh, Aceh. 23245 \\ 1. agustina.260880@gmail.com ; ${ }^{2}$ Ssah783@gmail.com
}

\begin{abstract}
Abstrak
Riset Kesehatan Dasar 2018 menyatakan proporsi balita stunting sekitar 39\%. Aceh menduduki peringkat ketujuh sebesar 41,5\%. Tujuan penelitian untuk mengetahui Hubungan Pemberian Asi Ekslusif, Berat Bayi Lahir dan Pola Asuh dengan Kejadian Stunting, dengan desain case control, sampel sebanyak 45 balita berusia 24-59 bulan. Analisis data menggunakan Chi-Square. Hasil penelitian bahwa ada hubungan Pemberian Asi Ekslusif ( $p$ value $=0,001)$, tidak ada hubungan antara Berat Bayi Lahir $(p$-value $=0,175)$, Pola Asuh $(p$ value $=0,189$ ) dengan Kejadian Stunting.
\end{abstract}

Kata Kunci: Stunting, Pemberian Asi Eksklusif, Berat Bayi Lahir, Pola Asuh

\begin{abstract}
Basic Health Research 2018 stated the proportion of stunted children around 39\%. Aceh was ranked seventh at $41.5 \%$. The purpose of this study was to determine the relationship of exclusive breastfeeding, birthweight and parenting with the incidence of stunting, with case control design. The sample was 45 toddlers aged 24-59 months. Data analysis using ChiSquare. The results of the study show that there is a relationship between exclusive breastfeeding $(\mathrm{p}$-value $=0.001)$, there is no relationship between birth weight $(\mathrm{p}$-value $=$ $0.175)$, parenting $(p-v a l u e=0.189)$ and the incidence of stunting.
\end{abstract}

Keywords: Stunting, Exclusive breastfeeding, birth weight, parenting

\section{PENDAHULUAN}

Permasalahan gizi buruk di Indonesia merupakan salah satu faktor penyebab kejadian stunting yang masih sangat tinggi jika dibandingkan dengan beberapa negara ASEAN. Kekurangan akan gizi kronis masih cukup tinggi sebesar 36,8\% balita. Penilaian malnutrisi kronis perlu dilakukan untuk mengetahui kesehatan anak dengan status gizi dalam jangka panjang, yang diukur dari tinggi badan menurut umur, dan digunakan sebagai indikator gizi disuatu daerah untuk mengetahui kasus pada anak saat ini. Indonesia menduduki rangking 
Journal of Healthcare Technology and Medicine Vol. 5 No. 2 Oktober 2019

Universitas Ubudiyah Indonesia

e-ISSN : 2615-109X

kelima dunia untuk jumlah anak dengan kasus stunting (Riskesda, 2013). Menurut Bappenas (2012), dalam mencapai tumbuh kembang yang optimal di dalam Global Strategy for Infant and Young Child Feeding, WHO/UNICEF merekomendasikan empat hal penting yang harus dilakukan yaitu : pertama memberikan Air Susu Ibu kepada bayi segera dalam 30 menit setelah bayi lahir, kedua memberikan hanya Air Susu Ibu (ASI) saja atau pemberian ASI secara Eksklusif sejak lahir sampai bayi berusia 6 bulan, ketiga memberikan Makanan Pendamping Air Susu Ibu (MP-ASI) sejak bayi berusia 6 bulan sampai 24 bulan, dan keempat meneruskan pemberian ASI sampai anak berusia 24 bulan atau lebih. Hal tersebut menekankan, secara sosial budaya MP-ASI hendaknya dibuat dari bahan yang murah dan mudah diperoleh dari daerah setempat (indegenous food) (Moehyi, S, 2008).

Pola asuh terhadap anak juga merupakan hal terpenting dalam membantu perkembangan dan pertumbuhan anak. Ibu memiliki peran yang besar dalam penyusunan menu makanan keluarga, sehingga ibu diharapkan memiliki pendidikan dan pengetahuan gizi yang tinggi (Adriani, M, dkk, 2012). faktor risiko stunting disebabkan oleh rendahnya pendapatan keluarga, menderita diare, menderita ISPA, rendahnya kecukupan energi, rendahnya tingkat kecukupan protein, salah satu orang tua pendek, berat bayi lahir rendah, tidak diberi ASI eksklusif, pemberian MP-ASI terlalu dini, dan pola asuh yang kurang baik. Stunting dipengaruhi oleh beberapa faktor seperti lingkungan, pemulihan menuju keadaan awal, gizi kurang, dan ada tidaknya penyakit. Stunting dapat menurunkan derajat kesehatan sehingga mudah terkena infeksi (WHO, 2014). Di Indonesia, sekitar 37\% (hampir 9 Juta) anak balita mengalami (Riset Kesehatan Dasar/Riskesdas 2013) dan di seluruh dunia, Indonesia adalah negara dengan prevalensi stunting kelima terbesar. Balita yang mengalami stunting akan memiliki tingkat kecerdasan tidak maksimal, menjadikan anak menjadi lebih rentan terhadap penyakit dan di masa depan dapat beresiko pada menurunnya tingkat produktivitas (TNP2K, 2018).

Berdasarkan laporan Riset Kesehatan Dasar (Riskesdas) tahun 2013, prevalensi stuntin secara nasional adalah $37,2 \%$, yang berarti terjadi peningkatan dibandingkan tahun 2010 (35,6\%) dan 2007 (36,8\%) (Riskesdas, 2013). Sedangkan Laporan Riset Kesehatan Dasar (Riskesdas) tahun 2018, diperoleh proporsi balita stunting sekitar 39\%. Masalah kesehatan masyarakat dianggap berat bila prevalensi pendek sebesar 30-39\% dan serius bila prevalensi pendek $\geq 40 \%$. Terdapat 14 provinsi di atas prevalensi nasional dan Provinsi Aceh menduduki peringkat ketujuh sebesar 41,5\%. Menurut WHO 2010, stunting dianggap sebagai 
Journal of Healthcare Technology and Medicine Vol. 5 No. 2 Oktober 2019

Universitas Ubudiyah Indonesia

e-ISSN : 2615-109X

masalah kesehatan masyarakat dengan kategori prevalensi tinggi bila prevalensi kependekan sebesar 30-39\% dan prevalensi sangat tinggi bila di atas atau sama degan 40\% (Riskesdas, 2018).

Berdasarkan indikator Tinggi Badan menurut Umur yang mengambarkan statuns gizi masa lampau (kronis) Balita Aceh mengalami stunting atau Tinggi badan dalam kategori pendek dan Sangat pendek, Keadaan ini jika dibandingkan di prevalensi stunting sebesar 8,9\% atau mendekati prevalensi stunting hasil PSG tahun 2014. Adapun kabupaten/kota yang paling tinggi kejadian stunting yaitu Subussalam 47,3\%, Aceh Selatan 44,9\% dan Pidie 43,7\% (Laporan PSG \& PKG Aceh, 2017).

Data dari Dinas Kesehatan Pidie menunjukkan jumlah keseluruhan balita sekitar 31863 dan jumlah balita yang di ukur hanya 30658 dengan jumlah balita di Pidie yang mengalami stunting sebanyak 3518 balita. Sehingga saat ini Pidie menduduki posisi nomor tiga tertinggi di Aceh berdasarkan laporan PSG tahun 2017. Dari 26 puskesmas di kabupaten Pidie dengan jumlah anak yang menderita stunting terbanyak berada di wilayah kerja Puskesmas Reubee dengan jumlah 259 anak (39\%). Kejadian stunting di wilayah Puskesmas Reubee berdasarkan laporan status gizi dinas kesehatan Pidie tahun 2017 disebabkan oleh rendahnya cakupan asi eksklusif $(8,8 \%)$ dan masih ada bayi yang lahir dengan Berat Badan Lahir Rendah (BBLR) sebesar 5,31\% (Laporan Status Gizi Pidie, 2017).

\section{METODE PENELITIAN}

Penelitian ini merupakan jenis penelitian deskriptif analitik dengan desain case control. Jumlah sampel sebanyak 45 balita usia 24-59 bulan yang mengalami Stunting di wilayah kerja Puskesmas Reubee Kabupaten Pidie dari bulan Januari hingga Agustus 2018 dari semua populasi 127 balita. menggunakan perbandingan antara kelompok kasus dan kelompok kontrol $1: 1$, dengan teknik proporsional sampling. Sumber data yang diperoleh adalah data primer dan data sekunder. Analisisi data dilakukan secara analisis univariat dan analisis bivariat.

\section{HASIL DAN PEMBAHASAN}

Hasil dari pengumpulan data yang dilakukan selama 10 hari terhitung sejak tanggal 2 Januari 2019 sampai dengan 12 Januari 2019 terhadap 90 sampel yang terdari 45 balita dari kelompok stunting (kasus) dan 45 balita dari kelompok normal (kontrol). 
Journal of Healthcare Technology and Medicine Vol. 5 No. 2 Oktober 2019

Universitas Ubudiyah Indonesia

e-ISSN : 2615-109X

\section{Analisa Bivariat}

Analisa bivariat bertujuan mencari hubungan antara variabel bebas dengan variabel terikat. Analisa bivariat pada penelitian ini dilakukan dengan menggunakan uji statistik Chi Square $\left(x^{2}\right)$ dan dinyatakan bermakna apabila $\mathrm{P}$ Value $<0,05$.

\section{Hubungan Pemberian ASI Eksklusif dengan Kejadian Stunting}

TABEL 1

HUBUNGAN PEMBERIAN ASI EKSKLUSIF DENGAN KEJADIAN STUNTING PADA BALITA DI WILAYAH KERJA PUSKESMAS REUBEE KABUPATEN PIDIE TAHUN 2019

\begin{tabular}{|c|c|c|c|c|c|c|c|c|c|c|}
\hline \multirow{3}{*}{ No } & \multirow{3}{*}{$\begin{array}{c}\text { Pemberian } \\
\text { ASI } \\
\text { Eksklusif }\end{array}$} & \multicolumn{4}{|c|}{ Kejadian Stunting } & \multirow{2}{*}{\multicolumn{2}{|c|}{ Total }} & \multirow{3}{*}{ OR } & \multirow{3}{*}{$\mathrm{Cl}(95 \%)$} & \multirow{3}{*}{ P-Value } \\
\hline & & \multicolumn{2}{|c|}{ Kasus } & \multicolumn{2}{|c|}{ Kontrol } & & & & & \\
\hline & & $\mathbf{F}$ & $\%$ & $f$ & $\%$ & $f$ & $\%$ & & & \\
\hline 1 & $\begin{array}{l}\text { Tidak ASI } \\
\text { Eksklusif }\end{array}$ & 43 & 95,6 & 17 & 37,8 & 60 & 66,7 & \multirow{3}{*}{35,41} & \multirow{3}{*}{$\begin{array}{l}7.58- \\
165.26\end{array}$} & \multirow{3}{*}{0,001} \\
\hline 2 & $\begin{array}{l}\text { ASI } \\
\text { Eksklusif }\end{array}$ & 2 & 4,4 & 28 & 62,2 & 30 & 33,3 & & & \\
\hline & Jumlah & 45 & 100 & 45 & 100 & 90 & 100 & & & \\
\hline
\end{tabular}

Sumber: Data Primer (diolah Januari, 2019)

Tabel 1 menunjukkan bahwa pemberian ASI eksklusif menjadi masalah besar di wilayah kerja Puskesmas Reubee dimana proporsi ibu-ibu yang tidak memberi ASI eksklusif lebih besar pada kelompok kasus yaitu 95,6\% dibandingkan dengan kelompok kontrol sebesar 37,8\%, sedangkan ibu-ibu yang memberi ASI eksklusif lebih besar pada kelompok kontrol yaitu 62,2\% dibandingkan pada kelompok kasus sebesar 4,4\%.

Hasil perhitungan diperoleh Odds Ratio 35,41 (95\% CI; 7.58-165.26). Ini menunjukkan bahwa balita yang tidak mendapat ASI Eksklusif memiliki risiko yang sangat besar yaitu 35 kali terhadap kejadian stunting dibandingkan dengan balita yang mendapakan ASI eksklusif pada balita di wilayah kerja Puskesmas Reubee kabupaten Pidie Tahun 2019.

Kurangnya pemberian ASI dan pemberian MP-ASI yang terlalu dini dapat meningkatkan risiko terjadinya stunting terutama pada awal kehidupan (Adair dan Guilkey, 1997). Besarnya pengaruh ASI eksklusif terhadap status gizi anak membuat WHO merekomendasikan agar menerapkan intervensi peningkatan pemberian ASI selama 6 bulan pertama sebagai salah satu langkah untuk mencapai WHO Global Nutrition Targets 2025 mengenai penurunan jumlah stunting pada anak di bawah lima tahun (WHO, 2014). 
Journal of Healthcare Technology and Medicine Vol. 5 No. 2 Oktober 2019

Universitas Ubudiyah Indonesia

e-ISSN : 2615-109X

Hal ini sesuai dengan penelitian Nadiyah (2014), perilaku ibu dalam pemberian ASI eksklusif memiliki hubungan yang bermakna dengan indeks $\mathrm{PB} / \mathrm{U}$, dimana 48 dari 51 anak stunted tidak mendapatkan ASI eksklusif. Selain itu penelitian ini juga sejalan dengan penelitian Indirawati Sri (2016), tentang hubungan pemberian ASI eksklusif dengan kejadian stunting pada balita 2-3 tahun. Dimana diperoleh p-value $=0,000(0,000<0,05)$. Maka disimpulkan bahwa terdapat hubungan pemberian ASI eksklusif dengan kejadian stunting pada balita 2-3 tahun. ASI merupakan asupan gizi yang sesuai dengan dengan kebutuhan akan membantu pertumbuhan dan perkembangan anak. Bayi yang tidak mendapatkan ASI dengan cukup berarti memiliki asupan gizi yang kurang baik dan dapat menyebabkan kekurangan gizi salah salah satunya dapat menyebabkan stunting.

\section{Hubungan Berat Bayi Lahir dengan Kejadian Stunting}

TABEL 2

HUBUNGAN BERAT BAYI LAHIR DENGAN KEJADIAN STUNTING PADA BALITA DI WILAYAH KERJA PUSKESMAS REUBEE KABUPATEN PIDIE TAHUN 2019

\begin{tabular}{|c|c|c|c|c|c|c|c|c|c|c|}
\hline \multirow{3}{*}{ No } & \multirow{3}{*}{$\begin{array}{c}\text { Berat Bayi } \\
\text { Lahir }\end{array}$} & \multicolumn{4}{|c|}{ Kejadian Stunting } & \multirow{2}{*}{\multicolumn{2}{|c|}{ Total }} & \multirow{3}{*}{ OR } & \multirow{3}{*}{$\mathrm{Cl}(95 \%)$} & \multirow{3}{*}{ P-Value } \\
\hline & & \multicolumn{2}{|c|}{ Kasus } & \multicolumn{2}{|c|}{ Kontrol } & & & & & \\
\hline & & $f$ & $\%$ & $f$ & $\%$ & $f$ & $\%$ & & & \\
\hline 1 & BBLR & 18 & 40 & 11 & 24,4 & 29 & 32,2 & \multirow{3}{*}{2,06} & \multirow{3}{*}{$0,83-5,09$} & \multirow{3}{*}{0,175} \\
\hline 2 & BBLN & 27 & 60 & 34 & 75,6 & 61 & 67,8 & & & \\
\hline & Jumlah & 45 & 100 & 45 & 100 & 90 & 100 & & & \\
\hline
\end{tabular}

Sumber: Data Primer (diolah Januari, 2019)

Tabel 2 menunjukkan bahwa berat bayi lahir menjadi masalah besar di wilayah kerja Puskesmas Reubee dimana proporsi balita yang lahir dengan berat bayi lahir rendah (BBLR) lebih besar pada kelompok kasus yaitu 40\% dibandingkan pada kelompok kontrol sebesar $24,4 \%$, sedangkan balita yang lahir dengan berat bayi lahir normal lebih besar pada kelompok kontrol yaitu 75,6\% dibandingkan dengan kelompok kasus sebesar $60 \%$.

Hasil perhitungan diperoleh Odds Ratio 2,06 (95\% CI; 0,83-5,09). Ini menunjukkan bahwa berat bayi lahir rendah (BBLR) berisiko 2,06 kali terhadap kejadian stunting dibandingkan dengan balita yang lahir dengan berat bayi lahir normal (BBLN) pada balita di wilayah kerja Puskesmas Reubee kabupaten Pidie Tahun 2019.

Bayi yang lahir normal juga dapat berisiko stunting jika asupan gizinya kurang. Kualitas dan kuantitas MP-ASI yang baik merupakan komponen penting dalam makanan balita karena mengandung sumber zat gizi makro dan mikro yang berperan dalam pertumbuhan linier (Soetjiningsih, 2012). 
Journal of Healthcare Technology and Medicine Vol. 5 No. 2 Oktober 2019

Universitas Ubudiyah Indonesia

e-ISSN : 2615-109X

Berbeda dengan penelitian ini ditemukan hubungan antara berat lahir dengan kejadian stunting pada balita. Balita yang memiliki berat lahir kurang mempunyai risiko 1,3 kali mengalami stunting dibandingkan dengan balita berat lahir normal. Hal ini sejalan dengan hasil penelitian di Pulau Sulawesi juga menunjukkan bahwa anak dengan berat lahir kurang dari 3000 gram memiliki risiko menjadi stunting 1,3 kali dibandingkan anak dengan berat lahir lebih dari atau sama dengan $3000 \mathrm{~g}$.

Oleh karena itu, anak yang lahir dengan berat badan kurang dibawah normal diwaspadai akan menjadi stunting. Semakin awal dilakukan penangulangan malnutrisi, maka akan semakin kecil risiko menjadi stunting. Bagi perempuan yang lahir dengan berat rendah, memiliki risiko besar untuk menjadi ibu yang stunted akan cenderung melahirkan bayi dengan berat lahir rendah sepeti dirinya. Bayi yang dilahirkan oleh ibu stunted tersebut akan menjadi perempuan dewasa yang stunted juga, dan akan membentuk siklus sama seperti sebelumnya (Kusumawardhani, 2017).

Semua kelompok lahir berisiko terhadap stunting hingga usia 12 bulan, dengan risiko terbesar pada kelompok anak IUGR (Intra Uterine Growth Retardation) dan risiko terkecil pada kelompok anak normal. Pada kelompok IUGR berkontribusi terhadap siklus intergenerasi yang disebabkan oleh tingkat ekonomi rendah, penyakit dan defisiensi zat gizi. Hal tersebut menunjukan bahwa, ibu dengan gizi kurang sejak awal sampai dengan akhir kehamilan akan melahirkan BBLR, yang kedepannya akan menjadi anak stunting (Lestari, W, dkk, 2014).

\section{Hubungan Pola Asuh dengan Kejadian Stunting}

TABEL 3

HUBUNGAN POLA ASUH DENGAN KEJADIAN STUNTING PADA BALITA DI WILAYAH KERJA PUSKESMAS REUBEE KABUPATEN PIDIE TAHUN 2019

\begin{tabular}{|c|c|c|c|c|c|c|c|c|c|c|}
\hline \multirow{3}{*}{ No } & \multirow{3}{*}{$\begin{array}{l}\text { Pola Asuh } \\
\text { Orang Tua }\end{array}$} & \multicolumn{4}{|c|}{ Kejadian Stunting } & \multirow{2}{*}{\multicolumn{2}{|c|}{ Total }} & \multirow{3}{*}{ OR } & \multirow{3}{*}{$\mathrm{Cl}(95 \%)$} & \multirow{3}{*}{ P Value } \\
\hline & & \multicolumn{2}{|c|}{ Kasus } & \multicolumn{2}{|c|}{ Kontrol } & & & & & \\
\hline & & $f$ & $\%$ & $f$ & $\%$ & $f$ & $\%$ & & & \\
\hline 1 & Tidak baik & 32 & 71,1 & 25 & 55,6 & 57 & 63,3 & \multirow{3}{*}{0,50} & \multirow{3}{*}{$0,21-1,21$} & \multirow{3}{*}{0,189} \\
\hline 2 & Baik & 13 & 28,9 & 20 & 44,4 & 33 & 36,7 & & & \\
\hline & Jumlah & 45 & 100 & 45 & 100 & 90 & 100 & & & \\
\hline
\end{tabular}

Sumber: Data Primer (diolah Januari, 2019) 
Journal of Healthcare Technology and Medicine Vol. 5 No. 2 Oktober 2019

Universitas Ubudiyah Indonesia

e-ISSN : 2615-109X

Tabel 3 menunjukkan bahwa pola asuh menjadi masalah besar di wilayah kerja Puskesmas Reubee dimana proporsi para ibu yang tidak memberikan pola asuh baik lebih besar pada kelompok kasus yaitu 71,1\% dibandingkan dengan kelompok kontrol sebesar $55,6 \%$, sedangkan para ibu yang memberikan pola asuh baik lebih besar pada kelompok kontrol yaitu 44,4\% dibandingkan dengan kelompok kasus yaitu sebesar 28,9\%.

Hasil perhitungan diperoleh Odds Ratio 0,50 (95\% CI; 0,21-1,21). Ini menunjukkan bahwa pola asuh tidak baik berisiko 0,50 kali terhadap Kejadian stunting dibandingkan dengan balita yang mendapat pola asuh baik pada balita di wilayah kerja Puskesmas Reubee kabupaten Pidie Tahun 2019.

Penelitian ini tidak sejalan dengan penelitian Sarah Brigitte, dkk (2012) yaitu adanya hubungan yang signifikan antara perhatian/dukungan ibu yang diklasifikasikan dalam pola asuh terhadap anak dalam praktek pemberian makanan, persiapan dan penyimpanan dengan pertumbuhan panjang badan anak dan kejadian stunting. Maka dapat dikatakan ibu yang memberikan perhatian dan dukungan terhadap anak dalam hal ini akan memberikan dampak positif pada keadaan status gizi anak, dimana digambarkan pada hasil penelitian ini yang menjawab cukup menunjukan 53,8\% panjang badan anak normal di wilayah pesisir Kecamatan Tallo. Perilaku ibu dalam menyusui atau memberi makan, cara makan yang sehat, memberi makanan yang bergizi dan mengontrol besar porsi yang dihabiskan akan meningkatkan status gizi anak.

\section{KESIMPULAN}

Berdasarkan hasil penelitian yang telah dilakukan tentang faktor-faktor yang berhubungan dengan kejadian stunting pada balita di wilayah kerja Puskesmas Reubee kabupaten Pidie tahun 2019, maka kesimpulan dalam penelitian ini adalah: Ada hubungan ASI Eksklusif dengan kejadian stunting pada balita di wilayah kerja Puskesmas Reubee kabupaten Pidie tahun 2019 dengan p-value $(0,001)$ dan OR $(35,41)$. Tidak ada hubungan berat bayi lahir dengan kejadian stunting pada balita di wilayah kerja Puskesmas Reubee kabupaten Pidie tahun 2019 dengan p-value $(0,175)$ dan OR $(2,061)$. Tidak ada hubungan pola asuh dengan kejadian stunting pada balita di wilayah kerja Puskesmas Reubee kabupaten Pidie tahun 2019 dengan $p$-value $(0,189)$ dan OR $(0,508)$.

\section{SARAN}

Bagi Puskesmas Reubee Kabupaten Pidie didarapkan dapat meningkatkan peran petugas kesehatan khususnya petugas Kesehatan Ibu dan Anak (KIA) Gizi dalam 
Journal of Healthcare Technology and Medicine Vol. 5 No. 2 Oktober 2019

Universitas Ubudiyah Indonesia

e-ISSN : 2615-109X

memberikan pelayanan atau penyuluhan yang menyeluruh, baik pentingnya gizi bagi ibu hamil, menyusui, bersalin bahkan bagi keluarga mengenai pentingnya menjaga gizi bayi, balita dan anak sehingga dapat mencegah terjadinya stunting. Bagi petugas puskesmas khususnya bagian kesehatan ibu dan anak diharapkan dapat meningkatkan pelayanan gizi dengan memantau dan memberikan penyuluhan pemberian ASI eksklusif baik kepada ibu dan ayah bayi bahkan untuk keluarga mengenai pentingnya ASI, ASI eksklusif dan menyusui hingga 2 tahun ditambah dengan MP-ASI yang sesuai dengan usia anak serta berusaha menurunkan kejadian penyakit infeksi pada anak baik diare, ISPA maupun penyakit lainnya sehingga dapat menekan angka kejadian stunting pada balita di masa yang akan datang.

\section{DAFTAR PUSTAKA}

Riskesdas. (2013). Status Gizi anak Balita Indonesia. Badan Penelitian dan Pengembangan Kesehatan Kementrian Kesehatan RI.

BAPPENAS. (2012). Kerangka Kebijakan Gerakan Sadar Gizi Dalam Rangka 1000 Hari Pertama Kehidupan (1000 HPK). Jakarta: Badan Perencanan Pembangunan Nasional.

Moehyi, S. (2008). Bayi Sehat Dan Cerdas Melalui Gizi Dan Makanan Pilihan. Jakarta: Pustaka Mina.

Adriani., M, \& Wijatmadi, B. (2012). Pengantar Gizi Masyarakat. Jakarta: Kencana Prenada Media Group.

WHO. (2014). WHA Global Nutrion Targets 2025 : Stunting Policy Brief. WHO Press: Geneva.

Tim Nasional Percepatan Penanggulangan Kemiskinan (TNP2K).(2018). Gerakan Nasional Pencegahan Stunting dan Kerjasama Kemitraan Multi Sektor. Jakarta.

Riskesdas. (2018). Status Gizi anak Balita Indonesia. Badan Penelitian dan Pengembangan Kesehatan Kementrian Kesehatan RI.

Laporan Studi Monitoring dan Evaluasi Program Gizi PSG \& PKG ACEH Tahun 2017.

Laporan Status Gizi Dinkes Pidie Tahun 2017.

Soetjiningsih. (2012). Tumbuh Kembang Anak. Edisi ke -2, Jakarta: EGC.

Kusumawardhani I. (2017). Asi Eksklusif, Panjang Badan Lahir, Berat Badan Lahir Rendah Sebagai Faktor Risiko Terjadinya Stunting Pada Anak Usia 6-24 Bulan Di Puskesmas Lendah Ii Kulon Progo. Department of Nutrition Poltekkes Kemenkes Yogyakarta. 
Journal of Healthcare Technology and Medicine Vol. 5 No. 2 Oktober 2019

Universitas Ubudiyah Indonesia

e-ISSN : 2615-109X

Lestari, W., Margawati, A., Rahfludin, M. Z. (2014). Faktor Risiko Stunting pada Anak Umur 6-24 Bulan di Kecamatan Penanggalan Kota Subulussalam Provinsi Aceh. Jurnal Gizi Indonesia; 3 (1): 126-134.

Sarah, Brigitte Dkk. (2012). Hubungan Pola Asuh Dengan Kejadian Stunting Anak Usia 6-23 Bulan Di Wilayah Pesisir Kecamatan Tallo Kota Makassar : Jurnal Kesehatan Masyarakat Universitas Hasanuddin Makassar. 